\title{
Response of Chickpea (Cicer Arietinum L.) To Compost and Indole-3-Butyric Acid under Rainfed Conditions
}

\author{
Essam. A.M. Osman; A. I. El-Shafie, K. A. Khatab and W. Kadry \\ Soils, Water and Environ. Res. Inst., Agric. Res. Center (ARC), Giza, Egypt.
}

\begin{abstract}
Drought stress is one of the most important a biotic stresses in agriculture worldwide, especially under rainfed conditions. Its impacts include reduction in growth, yield quantity and quality. The present experiment was carried out at the Agricultural Research Station of Mersa- Matruh, Mersa- Matruh Governorate, Egypt during 2014/2015 and 2015/2016 cropping seasons, to evaluate the effect of compost and spraying of indole-3butyric acid growth and yield of chickpea (Cicer arietinum $L$.) under rainfed conditions. Application of 4 ton compost fed ${ }^{-1}$ gave the highest significant values of plant height, branches and seed number plant ${ }^{-1}$ as well as capsules number and weight plant ${ }^{-1}$. Also, seed weight plant ${ }^{-1}$ and 100 seed weight as well as seed, straw and biological yield $\mathrm{fed}^{-1}$. In addition, NPK percentage in chickpea seed and straw as well as percentage of crude protein, total sugars and carbohydrates in both seasons. Spraying indole-3-butyric acid by the rate of $80 \mathrm{ppm}$ gave the highest significant values of all parameters under study. Foliar application of indole-3-butyric acid by the rate of $80 \mathrm{ppm}$ under 4 ton compost gave the highest significant values of all parameters in both seasons. Compost provides nutrients to the soil and improves water holding capacity. Spraying indole-3-butyric acid significantly reduces transpiration rate. Therefore, use of growth regulating substances and compost practices led to accomplish both acceptable chickpea yield quantity and quality.
\end{abstract}

Key words: Water saving, rainfed conditions, indole-3-butyric acid, compost, chickpea productivity.

\section{Introduction}

Grain legumes are vital crops for their protein rich seeds that used as a most important source of dietary protein for human and livestock consumption. Besides, legumes can be efficiently used for improving fertility of soils (Manchanda and Garg, 2008). Chickpea (Cicer arietinum L.) is an imperative legume crop grown and consumed all over the world, particularly in the Afro-Asian countries (Jukanti et al., 2012). Chickpea is the cheapest and readily available protein course (20.6), (Gupta, 1987). It is considered one of the most drought tolerant legume, and plays an important role in sustainable agriculture essentially in the semiarid areas of Mediterranean basin, (Pacucci et al., 2006). It is the third most important food legume after peas and soybean in the world. It is high in fiber and low in fat and thus healthy food source, especially, for persons with insulin sensitivity or diabetes. About $80 \%$ of the dry seed weight of chickpea comprises of carbohydrates and proteins as well as carbohydrates vary from 52 to $71 \%$ ( Abbas et al., 2013). Patil $\boldsymbol{e t}$ al., (2011) stated that the response of chickpea to organic fertilizers is a primary concern in its cultivation. Many options are available for accomplishing the nutrition of the crop with major nutrients. Some of the organic sources of nutrients are not only supply nutrients but also water to sustain the steady demand of the crop.

Drought stress is a major a biotic stress in agriculture worldwide. Its impacts include growth, yield, membrane integrity, pigment content, osmotic adjustment water relations and photosynthetic activity. Increasing crop tolerance to water stress would be the most economical approach to enhance productivity and reduce agricultural use of fresh water resources (Gao et al., 2008). Water plays a vital role in all living organisms (Önder et al., 2011). Compost can be an inexpensive fertilizer and source of plant nutrients. It is rich source of nutrients with high organic matter content. Physical and chemical properties of soil can be improved by adding compost fertilizer, which may ultimately increase crop yields. Consequently, use of compost is the need of the time. Positive effects of organic waste on soil structure, aggregate stability and waterholding capacity were reported in several studies (Jedidi et al., 2004 and Odlare et al., 2008). Compost has a high nutritional value, with high concentrations of nutrients especially $\mathrm{N}, \mathrm{P}$ and $\mathrm{K}$, while the contamination by heavy metals and other toxic substances are very low (Asghar et al., 2006). Physical properties like bulk density, porosity, void ratio, water permeability and hydraulic conductivity were significantly improved when FYM (10 t ha-1) was applied in combination with chemical amendments, resulting in enhanced rice and wheat yields (Hussain et al., 2001). Shahzad et al., (2014) concluded that the application of compost was more effective in increasing growth, and yield of chickpea in irrigated than rainfed farming systems. Also, added that the compost can promote agricultural yields with maximum benefits of symbiotic biological nitrogen fixation under water deficit environment. Yadav et al., (2017) studied the effect of different organic manures on growth and yield of chickpea, who found that a direct interaction 
between number of root nodules and higher $\mathrm{N}$ fixation, application of organics sources of vermicompost $2 \mathrm{t} \mathrm{ha}^{-1}$ and panchagavya3 per cent noticed higher number of total root nodules and effective root nodules which resulted in manifestation of higher growth and yield attributing characters as well as higher yield of chickpea. It could also been resulted because of effect of compost in holding soil moisture. Dahal et al., (2014) reported that residue treated soil delayed in maturity of maize with the same justification given above and the significant increased soil water holding capacity and Vengadaramana and Jashothan (2012) reported that compost and cattle manure increased water retention in soil.

The term plant hormone is a naturally happening chemical substance, which is an integral part of plant metabolism and in small concentrations can activate or depress any developmental process in that plant. Plant hormones which can be natural or synthetic are used extensively in agriculture, horticulture, and biotechnology to modify plant growth and development. Hormones regulate or influence arrange of cellular and physiological processes including cell division, cell enlargement, cell differentiation, flowering, fruit ripening, movement (tropisms), seed dormancy, seed germination, senescence, leaf abscission and stomatal conductance (Lwin et al.,2008). Amin et al., (2013) found that the foliar application with indole-3-butyric acid up to $100 \mathrm{mg} \mathrm{L}^{-1}$ greatly promoted the vegetative growth and dry matter production of branches, leaves and pods by enhancing cell division and chlorophyll accumulation. Abbas and El-Saeid (2012) reported that indole-3-butyric acid treatment increased endogenous gibbreleic acid concentrations in lemon grass by 10 and $23 \%$ compared with the control for plants treated with 25 and $100 \mathrm{ppm}$, respectively. Similarly, promoting effect of indole-3-butyric acid on growth and photosynthetic pigments was obtained on maize, onion and rice (Amin et al., 2006, 2007 and Chhun et al., 2004). Therefore, the present study aimed to evaluate the effect of compost and spraying of indole-3-butyric acid on the quantity and quality of Chickpea (Cicer arietinum L.), grown in Mersa- Matruh Governorate, Egypt under a rainfed conditions.

\section{Materials and Methods}

An experiment was carried out on chickpea (Cicer arietinum $L$.) to asses, its repose to compost and indole-3-butyric acid at the Agricultural Research Station of Mersa- Matruh, Mersa- Matruh Governorate, Egypt during 2014/2015 and $2015 / 2016$ cropping seasons. Some soil properties in the studied region are shown in Table 1.

Table 1. Physical and chemical properties of soil.

\begin{tabular}{|c|c|c|c|}
\hline \multirow{2}{*}{\multicolumn{2}{|c|}{ Properties }} & Season $2014-2015$ & Season $2015-2016$ \\
\hline & & \multicolumn{2}{|c|}{ value } \\
\hline \multirow{4}{*}{ Particle size distribution $(\%)$} & Coarse sand & 10.65 & 11.2 \\
\hline & Fine sand & 55 & 53.15 \\
\hline & Silt & 33.5 & 34.75 \\
\hline & Clay & 0.85 & 0.9 \\
\hline Textural class & & Sandy loam & Sandy loam \\
\hline $\mathrm{EC}_{\mathrm{e}}\left(\mathrm{dSm}^{-1}\right)$, soil paste & & 2.92 & 3.42 \\
\hline $\mathrm{pH}(1: 2.5)$ & & 7.55 & 8.36 \\
\hline $\mathrm{CaCO}_{3}(\%)$ & & 18.20 & 16.80 \\
\hline \multirow{4}{*}{ Soluble cations $\left(\mathrm{meqL}^{-1}\right)$} & $\mathrm{Ca}^{+2}$ & 4.8 & 5.5 \\
\hline & $\mathrm{Mg}^{+2}$ & 6.9 & 7.3 \\
\hline & $\mathrm{Na}^{+}$ & 15.3 & 15.2 \\
\hline & $\mathrm{K}^{+}$ & 1.8 & 2.1 \\
\hline \multirow{3}{*}{ Soluble ions $\left(\mathrm{meqL}^{-1}\right)$} & $-{ }_{3} \mathrm{HCO}$ & 8.1 & 8.6 \\
\hline & $\mathrm{Cl}^{-}$ & 12.2 & 12.4 \\
\hline & $\mathrm{SO}_{4}^{--}$ & 8.5 & 9.1 \\
\hline \multirow{3}{*}{ Available nutrients (ppm) } & $\mathrm{N}$ & 10.8 & 11.6 \\
\hline & $\mathrm{P}$ & 3.42 & 4.35 \\
\hline & $\mathrm{K}$ & 26.6 & 29.3 \\
\hline
\end{tabular}


The experiment was done as split plot design base on factorial in randomized complete blocks design with four repetitions. The treatments were consisted of three levels of compost (without, 2 and 4 ton / fed) and spraying different levels of indole-3-butyric acid (without, 50 and $100 \mathrm{ppm}$ indole-3-butyric acid / fed ). All seeds were inoculated with bacteria, the sugar solution $20 \%$ was prepared due to sticking bacteria to seeds and then seeds soaked with sugar solution and bacteria. Then seeds immediately planted after become dry in shade nitrogen required for each treatment was calculated and before planting and added to the ground.

Table 2. Some chemical analysis of the compost used in the study

\begin{tabular}{lcc}
\hline \multicolumn{1}{c}{ Parameters } & Season & \\
\hline ECe $\left(\mathrm{dSm}^{-1}\right)$ & $2014 / 2015$ & $2015 / 2016$ \\
pH & 1.57 & 1.98 \\
O C & 6.8 & 6.3 \\
OM & 28.82 & 27.62 \\
C/N & 49.69 & 47.62 \\
N \% & 15.33 & 16.54 \\
P \% & 1.88 & 1.67 \\
K \% & 1.18 & 1.15 \\
Fe (ppm) & 1.74 & 1.68 \\
Mn (ppm) & 532 & 513 \\
Zn (ppm) & 223 & 208 \\
Cu (ppm) & 221 & 202 \\
\hline
\end{tabular}

Chickpea seeds cultivars (Giza-3) were planted on $4^{\text {th }}$ week of November in the two seasons, after inoculated with Rhizobium strain and irrigated just after sowing.

Surface irrigation was applied in the first time only, but other irrigations were rainfed condition. The experimental unit area was $14 \mathrm{~m}^{2}$ consisting of five rows ( $4 \mathrm{~m}$ long and $70 \mathrm{~cm}$ between rows), $20 \mathrm{~cm}$ between hills. The normal agronomic practices of growing chickpea in this district were practiced till harvest as recommended by Legumes Research Dept. A.R.C., Giza.

$\mathrm{N}$ fertilizer was added at the rate of $15 \mathrm{~kg} \mathrm{~N} / \mathrm{fad}$. as ammonium nitrate $33 \% \mathrm{~N}$, nitrogen fertilizer was applied in two equal portion at 35 and 50 days after planting. While $\mathrm{P}$ fertilizer was added at the rate of $200 \mathrm{~kg} / \mathrm{fad}$., as calcium super phosphate $(15.0 \%$ $\mathrm{P}_{2} \mathrm{O}_{5}$ ). Potassium fertilizer was added at the rate of $24 \mathrm{~kg} / \mathrm{fad}$. as potassium sulfate, $48 \% \mathrm{~K}_{2} \mathrm{O}$, both $\mathrm{PK}$ fertilizers were added during the seedbed preparation. Indole -3-butryic acid was applied as a foliar spraying two times, i.e. 35 and 50 days after planting.

At full maturity, a random sample of ten plants was taken from each plot to determine the plant height $(\mathrm{cm})$, number of branches/plant, number of capsules/plant, weight of capsules (g/plant), seed weight (g/plant), and 100 seed weight. While, seeds, straw and biological yields per fad. were determined from the total plants of each plot.

Nitrogen was determined using micro Kjeldahl , while phosphorous was determined colourimetrically using ammonium molybdate and ammonium metavanadate according to the procedure outlined by Ryan et al.,(1996). Potassium was determined using the flame spectrophotometer method (Black, 1982).
$\mathrm{N}, \mathrm{P}$ and $\mathrm{K}$ uptake of grain, straw and biological yield were calculated. The technique used for total carbohydrates and sugars analysis was that proposed by Dubois et al., (1956).

Data collected for the above variables were subjected to statistical analysis using analysis of variance (ANOVA) technique (Snedecor and Cochran, 1980). The means were compared using Least Significant Difference (LSD) at $5 \%$ probability level according to Waller and Duncan (1969).

\section{Results and Discussion}

\section{Chickpea yield components}

Tabulated data in Table 4 reveal that the highest significant values of plant height, branches and seed number plant ${ }^{-1}$ as well as capsules number and weight plant $^{-1}$ were obtained by adding 4 ton compost fed $^{-1}$ in both seasons. The lowest values were recorded without addition of compost in both ones. This result may be due to the effect of compost in improving holding soil moisture, also, the compost might be due to the slow release of nutrients at early chickpea crop vegetative growth stages. In addition, chickpea growth characters were increased with compost because it increased soil microbial biomass and contents of available NPK of soil. The increase in soil available $\mathrm{N}$ of treatments with compost is closely related to the increase in organic matter content of soil. Organic $\mathrm{N}$ of compost can be slowly mineralized in soil. The increase in available $\mathrm{P}$ content might be due to organic acids, released during microbial decomposition of organic matter, which can solubilize native phosphates (Ramesh $\boldsymbol{e t}$ al., 2009). The higher availability of K may also be due to mineralization of compost. Indeed, the 
observed $\mathrm{K}$ content of soil amended with compost was higher than that of the soil fertilized with mineral fertilizers (Bulluck et al., 2002). According to Basak and Biswas (2009), unavailable $\mathrm{K}$ is converted into plant available form because of the acidic environment prevailing during composting.

Also, results show that the spraying indole-3butyric acid by the rate of $80 \mathrm{ppm}$ gave the highest significant values of all parameters under study in Table 4 compared to without spraying in both seasons, similar trend was noticed for branches number plant ${ }^{-1}$ when indole-3-butyric acid by the rate of $40 \mathrm{ppm}$ was spraying in the first season only. In this connection, Amin et al., (2013) stated that the foliar spry of indole-3-butyric acid caused more pronounced effect at $100 \mathrm{mg} \mathrm{L}^{-1}$ in promoting growth and yield of chickpea plants and attributed this to increase the nitrogen uptake and regulation of metabolic processes.

Regarding the interaction effect between compost rates and foliar spraying of indole-3-butyric acid on the abovementioned parameters in Table 4, data illustrate that the foliar application of indole-3butyric acid by the rate of $80 \mathrm{ppm}$ under 4 ton compost gave the highest significant values of all parameters in both seasons. Meanwhile, the lowest ones were recorded without spraying indole-3butyric acid under without compost in both ones. Ahmed Amal et al., (2015) concluded that chickpea plants grown under drought condition have a lower stomatal conductance in order to conserve water. Consequently, $\mathrm{CO} 2$ fixation is reduced and photosynthetic rate decreases, resulting in less assimilate production for growth plant. In this regard, Ahmed Amal et al., (2013) and , Zaki Nabila et al., (2013) reported that omitting one irrigation led to significant reduction in all growth characters.

\section{Chickpea yield}

Data in Table 5 demonstrate that the application of compost at rate of 4 ton fed $^{-1}$ gave the highest significant values of seed weight plant ${ }^{-1}$ and 100 seed weight as well as seed, straw and biological yield fed ${ }^{-}$ 1 compared to without compost addition in both seasons. The highest significant values of seed yield (267.39 and $367.61 \mathrm{~kg} \mathrm{fed}^{-1}$ ) in both seasons, respectively. The highest significant values of straw yield $\left(804.02\right.$ and $\left.898.72 \mathrm{~kg} \mathrm{fed}^{-1}\right)$ The highest significant values of biological yield (1071.41 and $1266.33 \mathrm{~kg} \mathrm{fed}^{-1}$ ) were obtained with application of compost at rate of 4 ton $\mathrm{fed}^{-1}$ in 2014/15 and 2015/16, respectively. These results show that the season of higher values for seed yield, was the 2015/2016 season, because it had the highest rainfall and because that rainfall was favorably distributed throughout the growing season. The highest yields for seed, straw and biological were obtained in this season. By contrast, the 2014/2015 season gave the lowest yields during this season (see Table $3 \mathrm{a}$ and $\mathrm{b}$ ). Compost addition can increase soil biological activity and improve physical and chemical properties. Also, stimulates microbial activity that in turn increases organic matter decomposition rate and nutrient dynamics (Chakraborty et al., 2011). Microbial biomass has vital role in regulating nutrient sources. Soil enzymatic activities are key determinants of soil available nutrient pools including N, P, and K (Sinsabaugh et al., 2009; Nannipieri et al., 2012).

Presented data in Table 5 show that the spraying indole-3-butyric acid at the rate of $80 \mathrm{ppm}$ led to significantly improvement of seed weight plant $^{-1}$ and 100 seed weight as well as seed, straw and biological yield fed- 1 compared to without spraying one in both seasons. The maximum values of seed yield (255.44 and $348.38 \mathrm{~kg} \mathrm{fed}^{-1}$ ) in the two seasons, respectively. The utmost values of seed yield (811.94 and $928.08 \mathrm{~kg} \mathrm{fed}^{-1}$ ) The maximum values of biological yield (1067.34 and $1276.46 \mathrm{~kg} \mathrm{fed}^{-1}$ ) were obtained with spraying of indole-3-butyric acid at the rate of $80 \mathrm{pmm}$ in 2014/15 and 2015/16, respectively. This spray significantly reduces transpiration rate, this may be due to increased stomatal resistance, which lead to conservation of moisture in the cells by maintaining high relative water content. These results are supported by Hatat et al., (2009) who found that the foliar application of indole-3-butyric acid significantly improved the nitrogen metabolism, photosynthesis and chickpea yield. Also, Amin et al., (2013) suggested that the photosynthetic pigments of chickpea leaves at 75 and 90 days from planting were significantly enhanced by application of indole-3-butyric acid. Additionally, they added that chickpea seed yield and quality were significantly enhanced by application of indole-3butyric acid, especially at the highest concentration (100 $\mathrm{mg} \mathrm{L}^{-1}$ ).

For the interacted effect between factors under study on such parameters in the same Table, data reveal that the spraying of indole-3-butyric acid by the rate of $80 \mathrm{ppm}$ with 4 ton compost gave the maximum significant values of all parameters in both seasons, meanwhile, the lowest ones were noticed without spraying indole-3-butyric acid under without compost in both ones. In general, data reveal that spraying of indole-3-butyric acid by the rate of 80 ppm with 4 ton compost surpassed without spraying indole-3-butyric acid under without compost, where chickpea seed, straw and biological yields were increased by ( 408.38 and $410.37 \%)$, (623.00 and $489.75 \%)$ and (556.08 and $465.10 \%)$ in $2014 / 15$ and 2015/16, respectively. These results are supported by Shahzad, et al., (2014) noted that the soil application of compost and spraying indole-3butyric acid gave the highest significant values of chickepea yield and its components under water limited conditions. 


\section{Macronutrients percentage}

Data in Table 6 reveal that the application of 4 ton compost per feddan achieved the highest significant values of NPK percentage in chickpea seed and straw in both seasons. While, the treatment of without compost addition gave the lowest significant values of same parameters in both ones. The increase in NPK percentage in chickpea seed and straw due to compost addition could be attributed to the positive effect of it in increasing the efficiency of chemical fertilizer by preventing losses of the nutrients through denitrification, volatilization and leaching and releasing with the passage of time. Compost could also improve the soil structure which leads to better root development which may result in more nutrient uptake from the soil in addition to its gradual/slow release of macro and micro nutrients by itself (Arshad et al., 2004).

Results show that the foliar application of indole3-butyric acid by the rate of $80 \mathrm{ppm}$ on chickpea plants gave the highest significant values of NPK percentage in seed and straw in both seasons. Similar trend was obtained for $\mathrm{N} \%$ of seed, $\mathrm{K} \%$ of straw and $\mathrm{P} \%$ of both in the first season, also, $\mathrm{N} \%$ of seed and straw in the second one. Meanwhile, the lowest ones were noticed without spraying of indole-3butyric acid in both seasons. In this connection, Amin et al., (2013) concluded that the foliar application of indole-3-butyric acid increased nitrogen, phosphorus and potassium in the dry seeds of chickpea notably due to their bio-regulatory effect on enzymatic activity and translocation processes from leaves to seeds, linking or converting to other plant metabolites.

Respecting the interacted effect between factors under study on such parameters in Table 6, data reveal that the spraying $80 \mathrm{ppm}$ of indole-3-butyric acid under 4 ton compost gave the greatest significant values of NK percentage in chickpea seed and straw in both seasons. The same trend was obtained for $\mathrm{N} \%$ of straw in the first season, and $\mathrm{N}$ $\%$ of seed and straw by adding 40 ppm of indole-3butyric acid under 4 ton compost in the second one. While, the lowest ones were noticed without spraying indole-3-butyric acid under without compost in both ones. Furthermore, $\mathrm{P} \%$ of seed and straw weren't affected significantly by the interacted effect between factors under study in both seasons.

\section{Percentage of crude protein, total sugars and total carbohydrates}

Available data in Table 7 demonstrate that the application of compost at the rate of 4 ton $\mathrm{fed}^{-1}$ led to the highest significant values of crude protein percentage, total sugars and total carbohydrates in chickpea plants comparing without compost addition in both seasons. The increase in crude protein , total sugars and total carbohydrates in chickpea plants according to compost addition may be due to the encouraging effects of it in improving the soil structure which leads to better root development, consequently results in more nutrient uptake from the soil in addition to its gradual/slow release of macro and micro nutrients by itself. The same results were reported by Khan et al., (2017) who suggested that compost has two main effects on soil properties, particularly in poor fertile soil. First, it improves organic matter content and then provides essential macro and micro nutrients for plant growth. Moreover, favorable special effects of compost is to increase water holding capacity and available plant water (Farrell and Jones, 2009).

Results show that, in most cases, spraying indole3-butyric acid by the rate of 80 or $40 \mathrm{ppm}$ on chickpea plants gave the highest significant values of crude protein percentage, total sugars and total carbohydrates in chickpea plants along without spraying of indole-3-butyric acid in both seasons. Amin et al., (2013) noted that the foliar application of indole-3-butyric acid increased crude protein, total sugars percent in the dry seeds of chickpea notably due to their bio-regulatory effect on enzymatic activity and translocation processes from leaves to seeds, linking or converting to other plant metabolites.

With regard to the interacted effect between factors under study on abovementioned parameters in Table 7, results illustrate that spraying indole-3butyric acid at $80 \mathrm{ppm}$ under 4 ton compost as a soil application gave the supreme significant values of all parameters in both seasons. While, the lowest ones were noticed without spraying indole-3-butyric acid under without compost in both ones. On the other hand, total sugars \% wasn't affected significantly by the interacted effect between factors under study in the first seasons. 

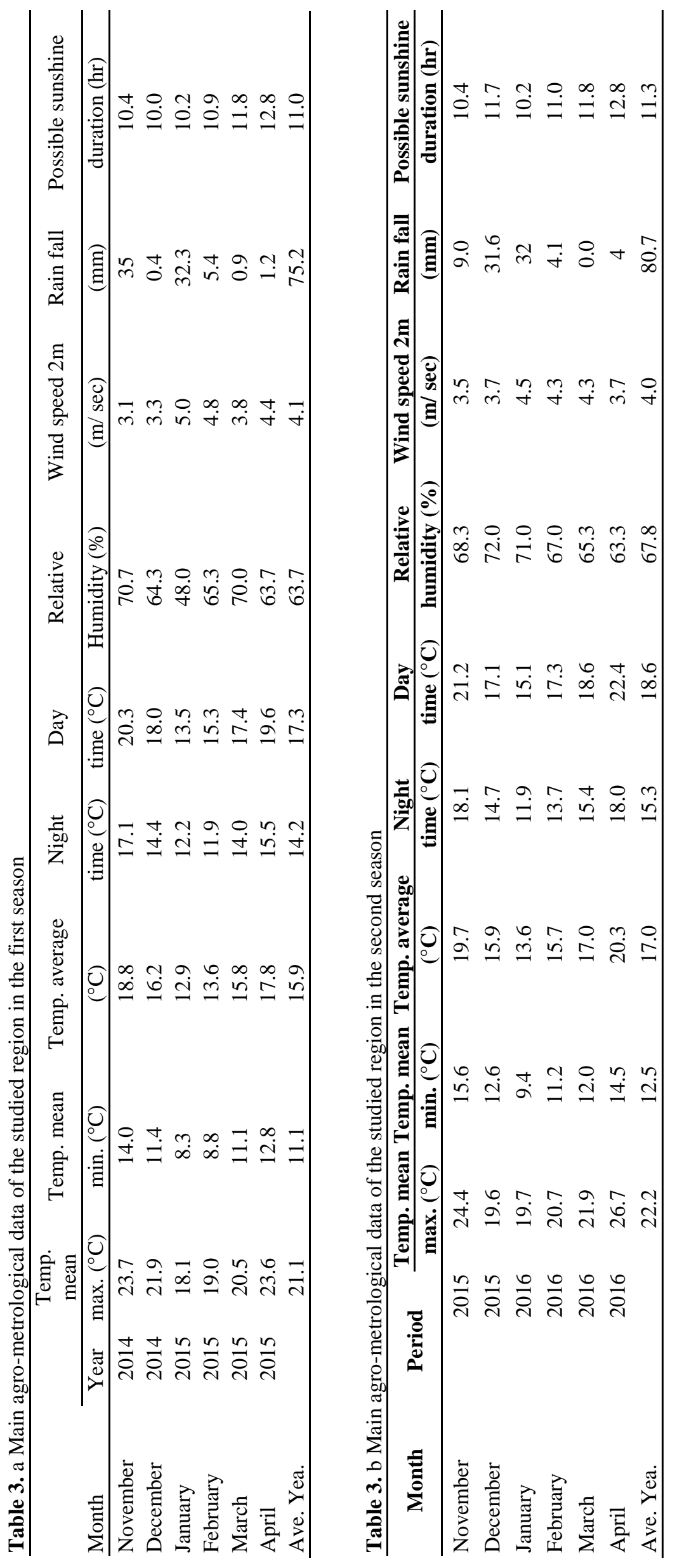


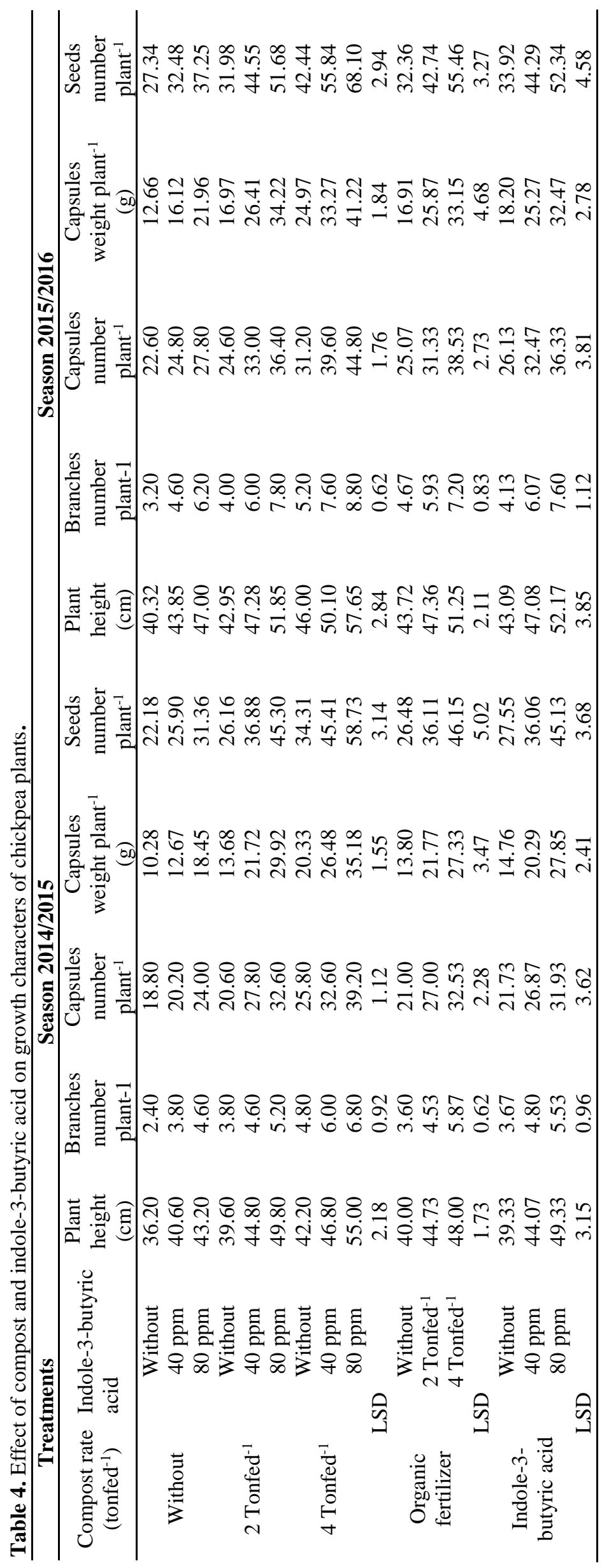




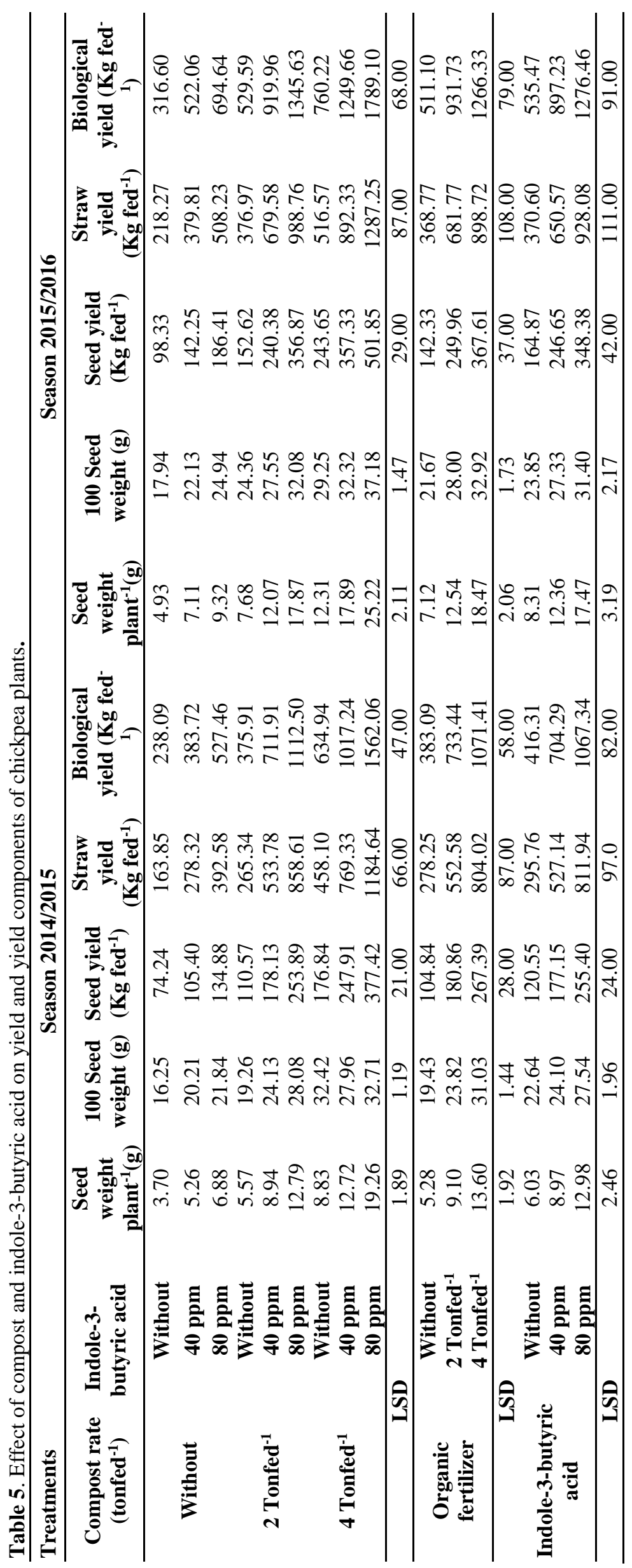




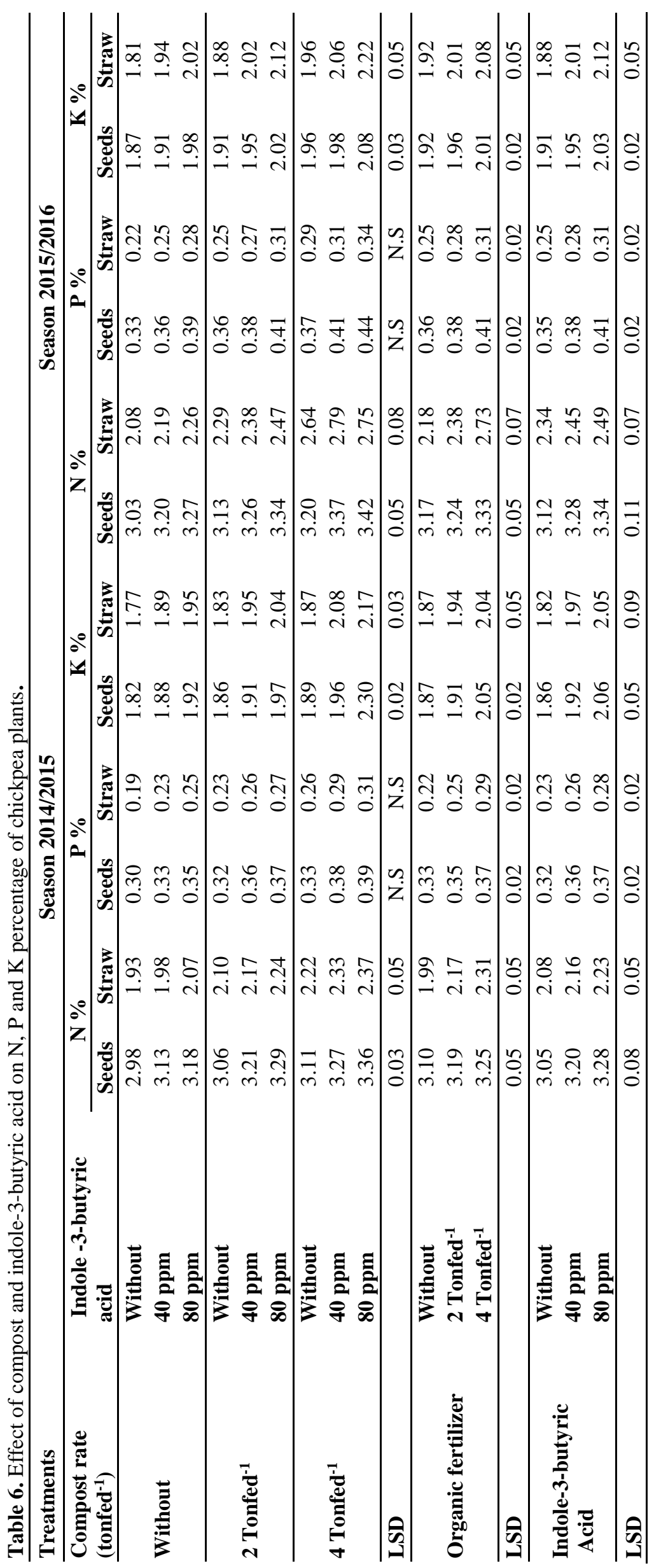




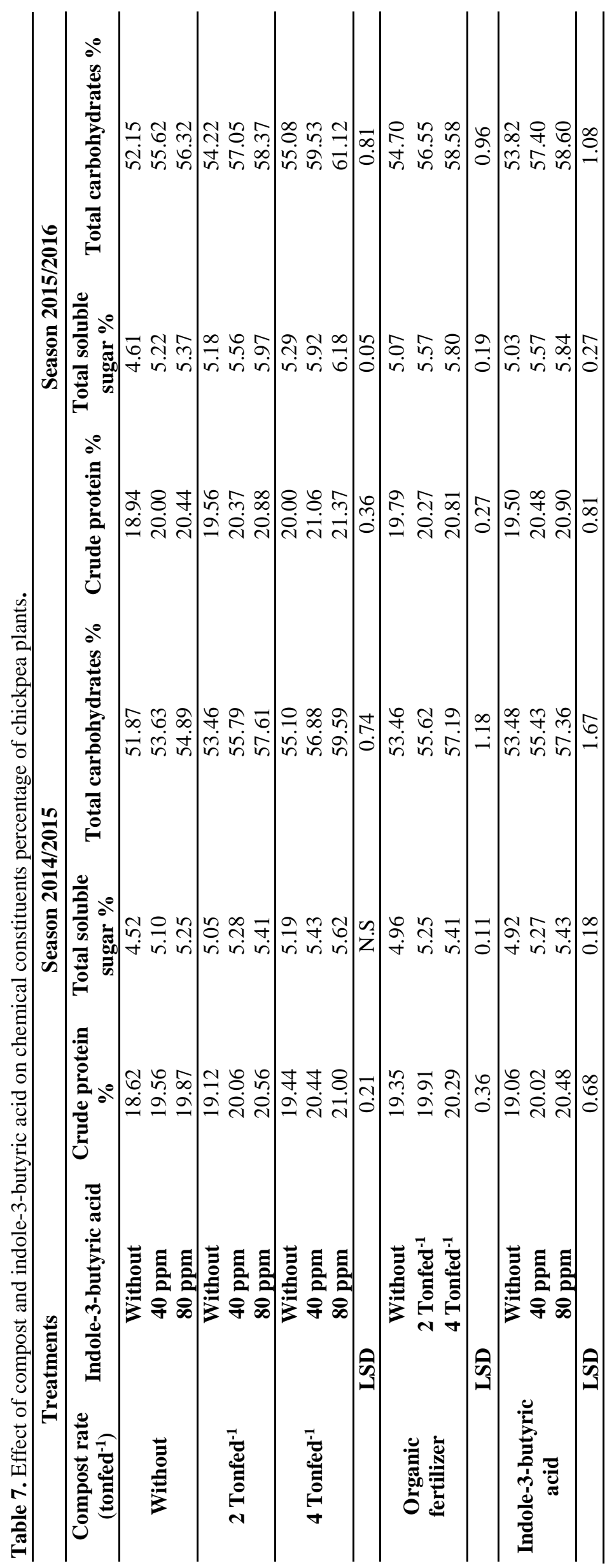




\section{Conclusion}

Vegetable cultivation under rainfed condition is not much popular while comparing to other systems of cultivation. However, it solves the problem of rural poverty and malnutrition. compost is regarded as a very important parameter of soil productivity. It has number of important roles to play in soils, both in their physical structure and as a medium for biological activity. It provides nutrients to the soil, improves its water holding capacity, and helps the soil to maintain good tilth and thereby better aeration for germinating seeds and plant root development. Spraying indole-3-butyric acid significantly reduces transpiration rate, this may be due to increasing stomatal resistance, which leads to conservation of moisture in the cells by maintaining high relative water content. Therefore, much concentration should be given for rainfed vegetable farming by efficient adoption of techniques viz., selection of varieties, seed treatment practices, use of growth regulating substances and compost practices. Under the same conditions, we can concluded that the application of 4 ton compost fed-1 with spraying indole-3-butyric acid interaction to accomplish both acceptable chickpea yield quantity and quality.

\section{Reference}

Abbas, S. M. and H. M. El-Saeid, 2012. Effects of some growth regulators on oil yield, growth and hormonal content of lemon grass (Cymbopogon citrates L.). Botanica Serbica, 36: 97-101.

Abbas,S. H., M. Sohail, M. Saleem, T. Mahmood, I. Aziz, M. Qamar, A. Majeed and M. Arif, 2013. Effect Of L-Tryptophan On Plant Weight And Pod Weight In Chickpea Under Rainfed Conditions, Sci., Tech. and Dev., 32: 277-280.

Ahmed, G. Amal, Nabila M. Zaki, Magda H. Mohamed, M. M. Tawfik and M. S. Hassanein, 2013. Growth and Yield Response of Two Chickpea Cultivars (Cicer arietinum L.) to Skipping One Irrigation. Middle East J. Agri. Res., 2: 146-151.

Ahmed, G. Amal, Magda H. Mohamed, M.S. Hassanein, Nabila M. Zaki, S.F. El Habbasha, M.M. Tawifk and Manal F. Mohamed. 2015. Effect of Water Regime and Potassium Fertilization on Productivity of Two Chickpea (Cicer Arietinum L.) Cultivars. /Int.J. ChemTech Res. 8: 1509-1519.

Amin, A. A., E. S. M. Rashad and F. A. E. Gharib, 2006. Physiological responses of maize plants (Zea mays L.) to foliar application of morphactin CF125 and indol-3-butyric acid. J. Boil. Sci., 6: 547-554.

Amin, A. A., E. S. M. Rashad and H.M. H. ElAbagy, 2007. Physiological effect of indol-3butyric acid and salicylic acid on growth, yield and chemical constituents of onion plants. J. Applied Sci. Res., 3: 1554-1563.

Amin, A. A., F.A. Gharib, H. F. Abouziena and Mona G. Dawood, 2013. Role of indole-3butyric acid or/ and putrescine in improving productivity of chickpea (Cicer arientinum L.) plants. Pakistan J. Boil. Sci, 16: 1894-1903.

Arshad, M., A. Khalid, M.H. Mahmood and Z.A. Zahir, 2004. Potential of nitrogen and Ltryptophan enriched compost for improving growth and yield of hybrid maize. Pak J Agric Sci., 41: 16-24.

Asghar, H.N., M. Ishaq, Z.A. Zahir, M. Khalid and M. Arshad, 2006. Response of radish to integrated use of nitrogen fertilizer and recycled organic waste. Pak J Bot., 38: 691-700.

Basak, B.B. and D.R. Biswas, 2009. Influence of potassium solubilizing microorganism (Bacillus mucilaginosus) and waste mica on potassium uptake dynamics by sudan grass (Sorghum vulgare Pers.) grown under two Alfisols. Pl. Soil 317:235-255.

Black, C. A., 1982. Methods of soil analysis. Part 2. Chemical and microbiological properties. Second Edition. Amer. Soc. of Agron. Madison, Wisconsin, U.S. A.

Bulluck, L.R., M. Brosius, G.K. Evanylo and J.B. Ristaino, 2002. Organic and synthetic fertility amendment influence soil microbial physical and chemical properties on organic and conventional farms. Appl Soil Ecol 19:147-160.

Chakraborty, A, K. Chakrabarti, A. Chakraborty and S. Ghosh, 2011. Effect of long-term fertilizers and manure application on microbial biomass and microbial activity of a tropical agricultural soil. Biol Fertil Soils 47:227-233.

Chhun, T., S. Takcta, S. Tsurumi and I. Masahiko, 2004. Different behaviour of indol-3acetic acid and indol-3-butyric acid in stimulating lateral root development in rice( Oryza sativa L.). Pl. Growth Regul., 43: 135-143.

Dahal, S, B.K. Tika, P.A. Lal, and K.B. Birendra, 2014. Tillage, residue, fertilizer and weed management on phenology and yield of spring Maize in Terai, Nepal. Int. J. Appl. Sci. Biot. 2: 328-335.

Dubois, M., K. A. Gilles, J. K. Hamilton, P. A. Rebers and F. Smith, 1956. Colorimetric method for determination of sugars and related substances. Analytical chemistry 28:350-356.

Farrell, M. and D. L. Jones, 2009. Critical evalution of municipal solid waste composting and potential compost markets. Biores. Technol. 100: 4301-4310.

Gao W.R., X.S.H Wang, P. Liu, J.G. Li, H. Zhang, 2008. Comparative analysis of ESTs in response to drought stress in chickpea (Cicer arietinume L.). Bioch. Bioph. Res. Commu., , 376, 578-583. 
Gupta, Y.P., 1987. Studies on chemical and nutritional changes in Bengal gram (Cicer arietinum) during storage caused by the attack of pulse beetle (Callosobruchus macuatus Fab.). Pl. Fd. Nutr., 37: 201-228.

Hatat, Q., S. Hayat, B. Ali and A Ahmad, 2009. Auxin analogues and nitrogen metabolism, photosynthesis and yield of chickpea. J. Pl. Nutr., 32: $1469-1485$.

Hussain, N., G. Hassan, M. Arshadullah and F. Mujeeb, 2001. Evaluation of amendments for the improvement of physical properties of sodic soil. Intl. J. Agric. Bio., 3:319-322.

Jedidi N, A. Hassen, O. Van Cleemput and A. M'Hiri, 2004. Microbial biomass in a soil amended with different types of organic wastes. Waste Manag. Res., 22: 93-99.

Jukanti, a. K., P. M. Gaur, C. L. L. Gowda and R. N. Chibbar, 2012. Nutritional quality and health benefits of chickpea (Cicer arietinum L.):A review. Br. J. Nutr., 108:511- 526.

Khan, A.A., H. Bibi, Z. Ali, M. Sharif, S.A. Shah, H. Ibadullah, K. Khan, I. Azeem, S. Ali, 2017. Effect of compost and inorganic fertilizers on yield and quality of tomato. Acad. J. Agric. Res. 5: 287-293.

Lwin, M. O., J.S. A. Stanaland and A. D. Miyazaki. (2008) Protecting children's privacy online: How parental mediation strategies affect website safeguard effectiveness. J. Retail. 84: 205-217

Manchanda, G. and N. Garg, 2008. Salinity and its effects on the functional biology of legumes. Acta Physiol. Pl., 30: 595- 618.

Nannipieri, P., Giagnoni L, Renella G, Puglisi E, Ceccanti B, Masciandaro G, Fornasier F, Moscatelli MC, Marinari S (2012) Soil Enzymology: classical and molecular approaches. Biol Fertil Soils 48:743-762CrossRefGoogle Scholar

Odlare M, M. Pell and K. Svensson, 2008. Changes in soil chemical and microbiological properties during 4 years of application of various organic residues. Waste Manag., 28: 1246-1253.

Önder O. M., E. Ceyhan and A. Kahraman, 2011. Effects of Agricultural Practices on Environment. Bio. Enviro. Chem., , 24, 28-32.

Patil, S. V., S. I. Halikatti, S. M. Hiremath, H. B. Babalad, M. N. Sreenivasa, N. S. Hebsur and G. Somanagouda, 2011. Effect of organic manures and rock phosphate on growth and yield of chickpea (Cicer arietinum L.) in vertisols, Karnataka J. Agric. Sci.,24 : 636-638.

Pacucci G, C. Troccoli, and B. Leoni, 2006. Effect of supplementary irrigation on yield of chickpea genotypes in a Mediterranean climate. Agric. Engin. Int. 8: Manuscript LW 04: 005.

Ramesh, P., N.R. Panwar, A.B. Singh, S. Ramana and A.S. Rao, 2009. Impact of organic manure combinations on the productivity and soil quality in different cropping systems in central India. J Pl. Nutr Soil Sci 172:577-585.

Ryan, J., S. Garabet, K. Harmsen, and A. Rashid, 1996. A soil and plant analysis manual adapted for the west Asia and North Africa region. ICARDA, Aleppo, Syria. 140pp.

Shahzad, S. M. , A. Khalid, M. S. Arif, M. Riaz, M. Ashraf, Z. Iqbal and T. Yasmeen, 2014. Coinoculation integrated with $\mathrm{P}$-enriched compost improved nodulation and growth of Chickpea (Cicer arietinum L.) under irrigated and rainfed farming systems. Biol. Fert. Soils 50: 1-12.

Sinsabaugh, R., B. Hill and J. Shah, 2009. Ecoenzymatic stoichiometry of microbial organic nutrient acquisition in soil and sediment. Nature 462:795-799.

Snedecor, G. W. and W. G. Cochran, 1980. One way classification-Analysis of Variance - The random effect model- Two way Classification (Eds) In Statistical Methods. The lowa State Univ. Press Ames lowa USA : 215-273.

Vengadaramana, A., and P.T. J. Jashothan, 2012. Effect of organic fertilizers on the water holding capacity of soil in different terrains of Jaffna peninsula in Sri Lanka. J. Nat. Prod. P1. Res. 2: 500-503.

Waller, R. A. and C. B. Duncan, 1969. Abays rule for symmetric multiple comparison problem Amer. State Assoc. Jour. December: 1485-1503.

Yadav, J. K., M. Sharma, R.N. Yadav, S.K. Yadav and S. Yadav, 2017. Effect of different organic manures on growth and yield of chickpea (Cicer arietinum L.), J. Pharm. Phytochem., 6: 18571860

Zaki Nabila, M. Amal G. Ahmed, Magda H. Mohamed, M. M. Tawfik and M. S. Hassanein, 2013. Effect of Skipping one Irrigation and Potassium Fertilization on Growth and Yield of Chickpea Plants. World Appl. Sci. J., 27: 557561. 


\section{استجابة الحمص للكمبوست وحامض اندول ثلاثى البيوتريك تحت ظروف الزراعه المطرية

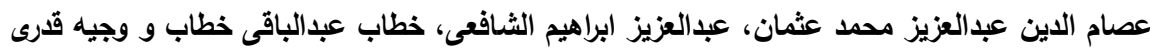

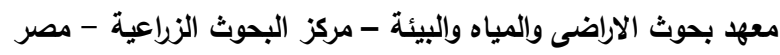

يعتبر الجفاف احد اهم العوامل المؤثرة على الزراعه عبر انحاء العالم، خاصة تحت ظروف الزراعه المطرية. وهذه الاثار تسبب انخفاض فى النمو وكمية وجودة المحاصيل. اقيمت هذه الدراسة فى محطة البحوث الزراعيبه بمرسى مطروح بمحافظة مرسى مطروح -مصر خلال الموسمين الزراعيين 2015/2014 و 2016/2015 لدراسة ناثير اضافة الكمبوست والرش بحامض اندول ثناثى البيوتريك لتحسين محصول الحمص كما ونوعا تحت ظروف الزراعه المطرية. وكانت اهم النتائج كما يلى: ادى اضافة 4 طن كمبوست الى زياده معنوية فى طول النبات وعدد الافرع والبذور / نبات وكذلك عدد ووزن الكبسولات / نبات. كما ادى الى زياده معنوية فى وزن البذور /نبات ووزن 100 بذرة وكذلك محصول البذور والقش والبيولوجى للفدان. بالاضافة للنسبة المئوية للنيتروجين والفوسفور والبوناسيوم فى بذور وقش الحمص ولثات وكذللك نسبة البروتين والسكريات الكلية والكربوهيدرات فى كلا الموسمين. ادى رش نبات الحمص بحامض اندول ثلانثى البيوتريك بتركيز 80 جزء فى في المليون لزياده

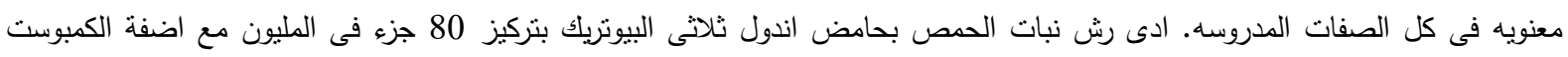

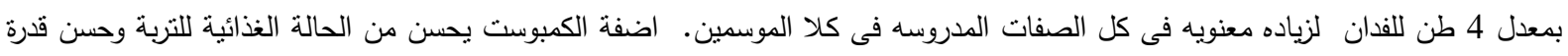
الارض على الاحتفاظ بالماء وان الرش بحامض اندول ثلاثى البيوتريك يقلل معدل البخر نتح للنبات. لذلك فان استخدام منظمات النمو واضافة الكمبوست ادى الى تحسين محصول الحمص كما ونوعا. 
